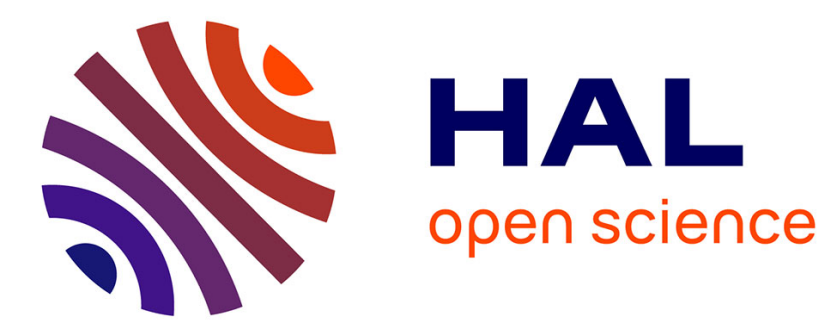

\title{
Does antibiotic prophylaxis really prevent streptococci infective endocarditis?
}

Didier Raoult, Cedric Abat

\section{To cite this version:}

Didier Raoult, Cedric Abat. Does antibiotic prophylaxis really prevent streptococci infective endocarditis?. Heart, 2018, 104 (4), pp.360. 10.1136/heartjnl-2017-312152 . hal-01791645

\section{HAL Id: hal-01791645 \\ https://hal.science/hal-01791645}

Submitted on 15 Apr 2019

HAL is a multi-disciplinary open access archive for the deposit and dissemination of scientific research documents, whether they are published or not. The documents may come from teaching and research institutions in France or abroad, or from public or private research centers.
L'archive ouverte pluridisciplinaire HAL, est destinée au dépôt et à la diffusion de documents scientifiques de niveau recherche, publiés ou non, émanant des établissements d'enseignement et de recherche français ou étrangers, des laboratoires publics ou privés. 


\section{CORRESPONDENCE}

\section{Does antibiotic prophylaxis really prevent streptococci infective endocarditis?}

\section{To the Editor,}

We read with interest the work presented by Cahill et $a l^{1}$ in which the authors evaluate the impact of antibiotic prophylaxis to prevent bactaeremia and infective endocarditis in patients undergoing dental procedures. The analysis was performed based on 36 studies, including 21 bacteraemia studies, five case controls and cohort studies and 10 time trend studies.

It is generally well established that dental cares cause bacteraemia and that most are due to streptococcal strains. ${ }^{12}$ It is, consequently, reasonable to think that prescribing antibiotics before dental cares decreases the incidence of such bacteraemia. Globally, the discordant results between the different kinds of studies analysed in the paper by Cahill $e t \mathrm{al}^{1}$ are clearly insufficient to conclude that antibiotic prophylaxis prevents bacteraemia due to streptococci. In our view, this observation can be explained by the fact that dental care is not the only cause of streptococcal bacteraemia. Indeed, such bacteraemia are extremely common, and it has been demonstrated that they can occur after chewing and after brushing in patients with periodontitis (cumulatively in $25 \%$ and $20 \%$ of cases, respectively). ${ }^{2}$ It is, therefore, fairly unlikely that bacteraemias due to dental cares are more responsible for endocarditis than other kinds of bacteraemias. In practice, this implies that the only reasonable antibiotic prophylaxis to prevent almost every bacteraemia due to oral streptococci would be lifetime treatment with penicillin or ampicillin. ${ }^{3}$ However, even doing so, it would be impossible to prevent all infective endocarditis, as the authors observe. $^{1}$

The main limitation of the study by Cahill $e a^{1}$ is that it did not include negative controls for bacteraemia and that the frequency of bacteraemia was measured only after dental care rather than after different day-to-day situations. This is an important methodological error which makes it an unreasonable basis for justifying particular conclusions.

Thus, and for the reasons mentioned above, there is still no evidence that antibiotic prophylaxis during dental care changes the incidence of infective endocarditis, ${ }^{4}$ and this is the only reasonable conclusion of this study.

\section{Didier Raoult, Cédric Abat}

URMITE, Aix MarseilleUniversité, IHU Méditerranée Infection, AP-HM, Marseille, Marseille, France

Correspondence to Professor Didier Raoult, URMITE, UMR CNRS 7278, IRD 198, INSERM U1095, IHU
Méditerranée Infection, Faculté de Médecine et de Pharmacie, Aix-Marseille Université, 27 boulevard Jean Moulin, 13385 Marseille CEDEX 05, France; Didier. Raoult@gmail.com

Contributors DR and CA wrote the paper.

Competing interests None declared.

Provenance and peer review Not commissioned; internally peer reviewed.

(C) Article author(s) (or their employer(s) unless otherwise stated in the text of the article) 2018. All rights reserved. No commercial use is permitted unless otherwise expressly granted.

$$
\text { A) Check for updates }
$$

To cite Raoult D, Abat C. Heart 2018;104:360

Received 13 July 2017

Accepted 14 July 2017

Heart 2018;104:360.

doi:10.1136/heartjnl-2017-312152

\section{REFERENCES}

1 Cahill TJ, Harrison JL, Jewell P, et al. Antibiotic prophylaxis for infective endocarditis: a systematic review and meta-analysis. Heart 2017;103:937-44.

2 Forner L, Larsen T, Kilian M, et al. Incidence of bacteremia after chewing, tooth brushing and scaling in individuals with periodontal inflammation. J Clin Periodontol 2006;33:401-7.

3 Diene SM, Abat C, Rolain JM, et al. How artificial is the antibiotic resistance definition? Lancet Infect Dis 2017;17:690.

4 Million M, Grisoli D, Griffiths K, et al. Antibiotic prophylaxis of endocarditis. Lancet Infect Dis 2016:16:773-4. 